\title{
BIVALVE AQUACULTURE AND EXOTIC SPECIES: A REVIEW OF ECOLOGICAL CONSIDERATIONS AND MANAGEMENT ISSUES
}

\author{
CHRISTOPHER W. MCKINDSEY, ${ }^{1 *}$ THOMAS LANDRY, ${ }^{2}$ FRANCIS X. O'BEIRN ${ }^{3}$ \\ AND IAN M. DAVIES ${ }^{4}$ \\ ${ }^{1}$ Fisheries and Oceans Canada, Institut Maurice-Lamontagne, 850 Route de la Mer, Mont-Joli, QC, \\ Canada, G5H 3Z4; ${ }^{2}$ Fisheries and Oceans Canada, Gulf Fisheries Centre, P.O. Box 5030, Moncton, NB, \\ Canada, E1C 9B6; ${ }^{3}$ Marine Institute, Rinville, Oranmore; ${ }^{4}$ Fisheries Research Services Marine \\ Laboratory, 375 Victoria Road, Aberdeen, UK, AB11 9DB
}

\begin{abstract}
Bivalves have been grown and transported for culture for hundreds of years and the introduction of some species outside of their native range for aquaculture has been suggested to be one of the greatest modes of introduction of exotic marine species. However, there has yet to be a thorough assessment of the importance of aquaculture and bivalve culture in particular, to the introduction and spread of exotic species. This paper reviews some of the environmental and ecological implications of the relationship between bivalve aquaculture and the introduction and spread of exotic species, management implications and mitigation strategies. Two broad classes of introductions of exotic species may result from activities associated with bivalve aquaculture. First, the intentional introduction of exotic species into an area for aquaculture purposes, i.e. the "target" species. These are typically foundation or engineering species and may have a considerable influence on receiving ecosystems. Second, the introduction of species that are either associated with introduced bivalves or facilitated by aquaculture activities (i.e. structures or husbandry practices). These may include both "hitchhiking" species (organisms that grow in association with or may be transferred with cultured bivalves) and disease causing organisms. Management options should include the use of risk assessments prior to transfers and quarantines. Various types of mitigation for exotic species have been evaluated but are generally not very successful. Because the risk of exotic species to ecosystems and the bivalve farming industry itself may be great, effort should be directed to better predict and halt introductions of potentially harmful species.
\end{abstract}

KEY WORDS: bivalve aquaculture, exotic species, introductions and transfers, risk assessment, mitigation

\section{INTRODUCTION}

The importance of aquaculture as a vector for the introduction and spread of exotic species, defined here as species that have been introduced to an area outside of their natural range, has been highlighted previously (Carlton 1992a, Carlton 1992b, Naylor et al. 2001, Streftaris et al. 2005). However, to our knowledge, there has yet to be a thorough assessment of the importance of aquaculture in general and bivalve culture in particular, to the introduction and spread of exotic species (but see Carlton 1992b). The mechanisms and factors associated with aquaculture that would mediate the introduction and spread of aquatic invaders need to be considered by environmental managers.

There are two broad classes of introductions that may result from activities associated with the culture of bivalves. First, there is the establishment and spread of exotic species that have been intentionally introduced into an area for aquaculture purposes (i.e., the "target" species). Classic examples of this include the introduction and naturalization of the Pacific oyster (Crassostrea gigas Thunberg) on the Pacific coast of North America (Ruesink et al. 2005) and in various countries throughout Europe (Grizel \& Heral 1991, Reise 1998, Drinkwaard 1999) and of the Mediterranean mussel (Mytilus galloprovincialis Lamarck) in South Africa (Branch \& Steffani 2004). It is likely that the underlying motive of many earlier introductions of exotic species for aquaculture purposes was to establish commercially and self-sustaining populations or to compensate for the disease loss. Second, there is the establishment and spread of species that are either associated with the introduced bivalves

*Corresponding author. E-mail: mckindseyc@dfo-mpo.gc.ca
(Carlton 1989, Carlton 1999) or facilitated by aquaculture activities (i.e., structures or husbandry practices). These species may include both "hitchhiking" species (animals and plants that grow in association with the bivalves) and disease causing organisms that may impact both target species and other species (Barber 1996). This acts at two spatial scales: at an interregional or international scale with respect to the initial introduction of hitchhiking species and also at a regional or local scale, where the transfer of stock among sites may be an important factor in the spread of established exotic species locally (Bourque et al. 2003). Other related vectors, such as processing plants for bivalves, are also of importance at a regional scale. The provision of novel habitat by cultured species and the cultivation environment may also facilitate for the establishment or amplification of exotic species that may be introduced by aquaculture or other vectors or of native species that might thrive with the provision of such novel habitat (Carver et al. 2003, Rodriguez 2005).

This paper reviews some of the environmental and ecological implications of the relationship between bivalve aquaculture and the introduction and spread of exotic species. Some management implications and mitigation strategies are also addressed. It must be highlighted that many of the observations reported in this review are likely not representative of bivalve aquaculture in general and may be rather extreme examples. Published information on the prevalence of any of the issues discussed is simply not available and we hope this review stimulates work to that end.

The majority of literature to date has been concerned with transfer of exotics in association with oyster culture, probably because this appears to be the dominant vector for all types of 
introductions (planned or otherwise) in bivalve aquaculture (Carlton 1992b). There is little published information about other bivalve species with respect to their function as exotic species or as vectors for other exotic species. Consequently, the following discussion is largely based on oyster-oriented literature but has been expanded where possible to include other taxa.

\section{HISTORY OF EXOTIC BIVALVE INTRODUCTIONS FOR AQUACULTURE AND THEIR ROLE AS VECTORS FOR OTHER EXOTICS}

The use of exotic bivalve species for aquaculture purposes may be because of a number of reasons. First, exotic bivalves may be considered to expand existing markets or to use species with the best growth or resistance to diseases or other environmental factors. Second, exotic species may also be considered to reduce development costs associated with new species (Hewitt et al. 2006). Whatever the reasons, the use of exotic bivalves for aquaculture purposes is now common practice in many areas.

Bivalves have been grown and transported for culture for hundreds of years (Mann 1983, Chew 1990). Oysters were grown on artificial structures by the Romans (Balon 1967b, cited in Balon 1995), and were held in parks in 7th century Greece (http://www.ifremer.fr/aquaculture/aquaculture/historique. htm). The first documented oyster (Ostrea edulis Linnaeus) transfers date back to at least 1714 in Europe (Wolff \& Reise 2002). Thereafter, transfers of $O$. edulis became routine, and attempts were made to introduce other species, (e.g., American oysters, Crassostrea virginica Gmelin) (circa 1870), Portuguese oysters (Crassostrea angulata Lamarck-actually a strain of C. gigas likely introduced with ship fouling) (imported from Portugal to France in latter half of 19th century), and C. gigas (1903) (Wolff \& Reise 2002). Mussel spat capture and grow-out started in the 13th century in Europe (http://www.mytiliculture. com/spip.php?article7). In North America, serious efforts to introduce exotic species of bivalves for culture started on the west coast with the attempted introduction of $C$. virginica in Puget Sound, WA, in the 1870 to 1880s and was ongoing until the 1920s and in British Columbia from the 1880s until the 1930s (Wonham \& Carlton 2005). Effort was subsequently directed towards introducing $C$. gigas on the west coast, with an initial attempt in Puget Sound in 1875 and ongoing with efforts there from 1902 onwards, and in British Columbia starting in 1912 to 1913 (Wonham \& Carlton 2005). Many attempts have been made to introduce $O$. edulis to both coasts, starting in 1949 to 1961 in the eastern United States and 1957 to 1959 in eastern Canada and on the west coast after this (Chew 1990, Carlton 1992a, Shatkin et al. 1997, Vercaemer et al. 2003, Ruesink et al. 2005).

Introductions of $C$. gigas and to a lesser extent of $C$. virginica and other oyster species, outside of their native range for aquaculture have been suggested to be one of the greatest single modes of introduction of exotic marine species world-wide (Wasson et al. 2001, Ruesink et al. 2005). For example, the transfer of organisms with bivalves has been suggested to be the dominant source of exotic species in northern Europe (Minchin 1996, Streftaris et al. 2005) and among the most important vectors elsewhere on that continent (Ribera Siguan 2003, Streftaris et al. 2005). In the north east Pacific, some authors suggest that oyster introductions have even been the major source of introduction of exotic molluses (Carlton 1992) and invertebrates in general (reviewed in Carlton \& Mann 1996;
Wonham \& Carlton 2005), historically contributing at least as many of the exotic species to that area as international shipping. The importance of the relationship between aquaculture activities and the introduction and spread of exotic species has been highlighted by Carlton (1999) who observed that there are relatively few introductions of exotic species associated with bivalve culture on the eastern seaboard of North America, where most of the cultured species are indigenous (Boghen 1995), as compared with western North America, where most of the cultured species are exotic.

\section{Bivalves and Bivalve Aquaculture as Habitat and Ecosystem Effects}

Bivalves, especially large forms found in dense aggregations, similar to those grown in aquaculture, may have a considerable influence on the ecosystem (Crooks 2002) and their effect may extend beyond the communities of exotic bivalves themselves and into adjacent habitats (Dame 1996). All bivalves that are currently cultured to any extent are "foundation" species (Dayton 1972), meaning that they are relatively large, dominant in terms of biomass or abundance, and have a positive effect on community inhabitants as a consequence of their physical presence and not their actions. As such, they facilitate or otherwise influence benthic communities by creating general habitat, providing refuge from predation, reducing physical and physiological stress, enhancing settlement and recruitment, and increasing food supply (Bruno \& Bertness 2001). Dense bivalves communities have also been shown to have a number of other important ecosystem effects, including, inter alia, altering nutrient fluxes, planktonic communities, etc. (Dame 1996).

Bivalve culture has the potential to increase the threedimensional structure of the physical environment via both the physical structure of the equipment used (buoys, lines, trays, bags, rafts, netting, etc.) and the cultured bivalves themselves. The habitat modification associated with suspended or offbottom culture practices can be particularly pronounced in areas previously devoid of any relief or hard substrate (e.g., flat sand or mud dominated). The physical structures associated with bivalve aquaculture afford both foraging and refuge opportunities for different species, either directly or else indirectly through colonizing species (Bartol \& Mann 1997, O’Beirn et al. 2000, Shumway et al. 2003). Organisms growing on bivalves in culture may in turn attract other organisms, such as fish and more mobile macroinvertebrates (Carbines 1993) as well as fouling species (Lawrence et al. 2000). Hence, many studies have noted great abundances and biomass of organisms living associated with bivalves in suspension, on-bottom and off-bottom culture (Tenore \& González 1976, Castel et al. 1989, Khalaman 2001, Luckenbach 2001, LeBlanc et al. 2002, Dealteris et al. 2004, O'Beirn et al. 2004, Guenther et al. 2006, see review in McKindsey et al. 2006). Indeed, bivalve farmers are constantly searching for ways to reduce the abundance of fouling organisms on their stock and equipment to increase their growth, facilitate field maintenance and processing (see reviews in LeBlanc et al. 2003, Ross et al. 2004) and increase marketability. As with natural bivalve communities, bivalve aquaculture communities may have a variety of near- and farfield cascading effects on different parts of the ecosystem, including influencing primary and secondary productivity and community structure (see reviews in Broekhuizen et al. 2002, McKindsey et al. 2006, Anderson et al. 2006). Although 
Ruesink et al. (2005) suggest that the role of oysters as foundation species is "particularly pronounced" in soft-sediment habitats lacking other hard substrate, it is equally likely that the importance of these and other taxa will be as great in suspension and off-bottom culture as this too creates novel habitat.

Endemic and exotic species in culture are likely to have similar effects directly associated to the culture activities (i.e., near-field effects). Endemic species, especially those being captured from wild sources, are likely to have little effect on background populations of the wild population and thus may have limited far-field effects, although mussel spat harvested from the wild for grow-out on farms has been suggested to be susceptible to overexploitation in some areas (Beadman et al. 2002). In contrast, cultured exotic species that are capable of reproducing in farm operations and to spread beyond their confines may have more dramatic far-field effects. In fact, recent modeling work (Cuddington \& Hastings 2004) suggests that exotic foundation species may have the greatest effects on the receiving ecosystems because of the ways in which they may modify the physical habitat. Surprisingly, few studies have examined the influence of exotic bivalves that have spread from aquaculture sites on the environment and even fewer studies have involved manipulative experiments. Clear expressions of this effect can be found in the Oosterschelde in the Netherlands and the German Wadden Sea, where oyster (C. gigas) introduced for culture purposes have naturalized and established self-sustaining populations (Dijkema 1997, Seaman and Ruth 1997). These populations are considered a nuisance for existing aquaculture operations (i.e., mussel culture) and conservation goals (Smaal et al. 2005, Diederich 2006).

The ability to predict whether an exotic bivalve that has been introduced into an area will establish, propagate and spread is an imprecise science (Shatkin et al. 1997, Ruesink et al. 2005), much as it is in general in invasion biology (Lodge et al. 1998, Ricciardi \& Rasmussen 1998, Heger \& Trepl 2003). In short, the ability of a given species to establish is a function of how well the environment in which it finds itself provides for its needs in terms of food and habitat availability, its reproductive capacity (including dispersal ability), and interspecific interactions with the local flora and fauna as well as abiotic factors.

The influences of exotic bivalves on benthic communities that lack such foundation species are in accord with principles in the ecological literature. In general, the addition of exotic oysters to soft-sediment areas leads to an increase in the abundance of most groups of organisms. In one of the rare manipulative experiments to evaluate the influence of an introduced bivalve, Escapa et al. (2004) showed that the presence of intertidal $C$. gigas beds increased the abundance of both infauna and epifauna as well as that of birds relative to adjacent control areas without oyster beds. Similarly, observational studies done in Washington State (Dumbauld et al. 2000, Hosack 2003, cited in Ruesink et al. 2005) have shown that the diversity and abundance of various groups of organisms in mud flats are increased by the presence of $C$. gigas beds. The influence of exotic oysters on hard substrate-associated species is variable and often indirect. For example, C. gigas on rocky coasts in British Columbia tends to occupy the high intertidal zones and, far from limiting the abundance of the normal barnacle community in that zone, actually increases the surface area for the barnacles (Bourne 1979, cited in Ruesink et al. 2005). C. gigas has also been observed to recruit to mussel beds on both rocky coasts (Orensanz et al. 2002) and mudflats and established mussel (M. edulis) reefs (Wolff \& Reise 2002; Diederich 2005, Diederich 2006), slowly transforming the former mussel beds into oyster reefs. However, some of these observed changes might be facilitated by factors other than competitive exclusion such as milder winters recently experienced in the German Wadden Sea (Nehls et al. 2006).

Although often understandable in hindsight, the influence of exotic bivalves on the functioning of the benthic and/or intertidal ecosystem is very difficult to predict. Branch and Steffani (2004) provide an excellent review of one case $(M$. galloprovincialis in South Africa). In short, their findings suggest that although some of the mussel's effects may have been predicted with good information on the local biology and ecology, some are only understandable in hindsight as the diversity of interactions between the mussel and the local fauna and the environment make it difficult to predict all potential effects.

Biological properties that can facilitate the establishment and spread of invasive species include rapid growth under a range of environmental conditions, tolerance to a range of physiological stress, and great reproductive output (Ruiz et al. 2000, Cox 2004). These are similar to some of the attributes that are sought for aquaculture species (Branch \& Steffani 2004, National Research Council 2004). In general, introduced species and native congeners or their approximate ecological bivalve equivalents (e.g., mussels and oysters) differ in their environmental requirements such that strong competitive interactions between them may be limited. That being said, Ruesink et al. (2005) list examples of oyster species with overlapping habitat requirements and show that exotic oysters consistently outgrow and basically dominate endemics. The same is true for mussels. Branch and Steffani (2004) show how the introduced $M$. galloprovincialis has largely replaced one of the endemic species of mussels (Aulacomya ater Molina) on rocky coasts in South Africa, because the two species overlap greatly in their basic life requirements but that the growth, reproductive output, tolerance to stress, disease resistance, and survivorship are greater for $M$. galloprovincialis. In contrast, the two other sympatric mussels, Perna perna (Linnaeus) and Choromytilus meridionalis (Krauss), are much less affected, because their basic life requirements differ from those of M. galloprovincialis.

The risk of an introduced species replacing an endemic one in terms of function in the benthos depends on the ecological similarity of the two species. In many instances, congeners are not ecological equivalents. For example, considering only physical structure, neither $C$. gigas nor Crassostrea ariakensis (Fujita) form the expansive high-relief reefs that $C$. virginica does within its native range. So, although either of these nonendemic species may in some way replace the filtration capacity and nutrient cycling services that $C$. virginica normally provides, it is not likely that either would be able to provide the ecological services associated with the physical structure provided by C. virginica. Similarly, many authors (Suchanek 1979, Suchanek 1981, Suchanek 1985, Seed \& Suchanek 1992, Iwasaki 1994, Iwasaki 1995, Seed 1996) have shown that different species of mussels differ greatly in the type of threedimensional structure that they create in the natural habitat (e.g., monolayers versus multiple layers of mussels, different densities of byssus and mussels, different sizes, and so forth) and thus would likewise alter any system in which they replaced 
local species, as is occurring in South Africa (Griffiths et al. 1992).

Dense aggregations of bivalves also have the potential to significantly influence water column and water column-benthic interactions (Gosling 1992, Dame 1996). However, as pointed out for benthic processes, different bivalve species may differ in how they effect this and the expansion of an introduced bivalve species may have complex cascading effects on water column and nutrient dynamics. This could also be the case for species that have direct or indirect impacts on bivalve species or other foundation species in an ecosystem. Such interactions remain largely unstudied to date.

\section{Exotic Hitchhikers}

The majority of exotic marine species recorded are benthic and, more specifically, hard-bottom associated species (Gollasch 2006). Further, the majority of aquatic exotic species are also associated with coastal areas, particularly estuaries and lagoons (Nehring 2006, Reise et al. 2006), and exotics in general commonly exploit novel and/or disturbed habitats (Ruiz et al. 2000). Thus, as bivalve culture sites are commonly sited in areas that have this suite of conditions and/or help create these conditions, bivalve culture may serve to focus exotic species. Further, because of the great diversity of associated species in bivalve culture, relaying or stock transfers among regions may be an important vector for the introduction and/or spread of exotic species even if the target species is found within these broad geographic regions.

There are numerous ways in which exotic species may be introduced into a new environment when bivalves are transferred for aquaculture. Exotics may be present within the bivalves, on the bivalves, in water or on equipment (such as ropes, socking material, cages) transferred with the bivalves, within sediment transferred within empty shells of dead individuals, or associated with other hitchhiking species. The importance of the different modes of transfer varies with culture type and stage of both the bivalves and the exotic species (Buhle et al. 2005).

There are three major classes of exotic hitchhikers of concern with respect to bivalve aquaculture and introductions and transfers: (1) exotic macrospecies including algae and animals; (2) exotic phytoplankton (toxic and otherwise); and (3) exotic disease causing organisms. Each of these may influence the bivalve species being cultured or the surrounding ecosystem. Although not all exotic species associated with bivalve aquaculture may have initially been introduced with the practice, all are facilitated by it such that bivalve culture may play an important role in their initial establishment and expansion as well as their secondary spread. Each may also have significant feedback and additive effects on both the bivalves in culture and on the local environment, respectively.

\section{Exotic Macrospecies}

Exotic macrospecies of invertebrates and algae may affect the bivalves with which they are associated in culture and the environment in general once introduced along with bivalves for aquaculture. It must be noted that the literature dealing with this subject is quite limited and much of the available information is only available in the "grey literature," including reports and conference proceedings.
The most obvious and immediate effect of exotic macrospecies on aquaculture is the fouling of cultured bivalves and related equipment (lines, cages, buoys, etc.). A current example is the suite of tunicates that is troubling the mussel industry in Prince Edward Island (PEI), eastern Canada (i.e., the solitary tunicates Styela clava Herdman and Ciona intestinalis Linnaeus and the colonial species Botrylloides violaceus Oka and Botryllus schlosseri Pallas, known commonly as the clubbed, vase, violet, and golden star tunicates, respectively), and another species that is fouling bivalve culture sites in British Columbia, Didemnum sp., which has also been reported off the coast of Nova Scotia, eastern Canada, and the northeast coast of the United States (Kott 2002, Kott 2004). These and other species are also problematic for bivalve culture in the northeastern United States (Bullard et al. 2005, Getchis 2005). It has been suggested that at least some of these tunicates have been introduced and/or spread through bivalve aquaculture (Lambert and Lambert 1998). Fouling organisms such as tunicates are likely to compete directly with bivalves in culture for food and space, potentially reducing growth rates and increasing stress and mortality (Lesser et al. 1992, Bourque et al. 2003, Carver et al. 2003). That being said, bivalves and fouling tunicate species feed on different types of food such that competition between mussels and tunicates is species-specific. For example, $S$. clava and M. edulis feed on similar sized food (Bourque et al. 2003) whereas C. intestinalis and M. edulis feed on different sizes of food (Lesser et al. 1992). Under the latter scenario, Lesser et al. (1992) suggest that the mussel and fouling species are not likely to compete strongly for food and that the latter should not influence mussel yield unless food is a limiting factor. However, this does not take into account the simple physical barrier that the tunicates create, which may reduce the availability of food to the mussels underneath. The presence of such large filter-feeders may also filter out large quantities of seston and potentially change the local carrying capacity for bivalve culture. The presence of such abundant and large macrospecies in association with or adjacent to bivalve culture operations also has a great impact on general operations within the culture sites and for processing as all the lines, etc. used are all much heavier and the tunicates can impede the efficiency of the processing equipment.

The green crab Carcinus maenas Linnaeus is an introduced species in North America where it is a concern for bivalve aquaculture operations. The green crab is a voracious predator and has a preference for bivalves (Behrens Yamada 2001). On the Atlantic coast of North America, it has been blamed, in part, for the decline of the softshell clam population (Glude 1955). Floyd and Williams (2004) suggest that farmers will have to protect the young clams until they reach a size at which they are no longer vulnerable to the crab. It is also common on mussel lines and scallop cages in areas where it is widespread (McKindsey, personal observations) and thus it may also have an effect on these types of bivalve culture. The invasive skeleton shrimp (Caprella mutica Schurin) seems to be widespread along both coasts of the north Atlantic and is believed by some farmers to be responsible for a decline in mussel spat-fall in Canada and Europe (Cook et al. 2004). Once again, little research to date has addressed these issues.

A number of exotic species introduced with bivalve culture are also having significant effects of that same industry in 
Europe. For example, the slipper shell Crepidula fornicata (Linnaeus) was introduced to Europe with $C$. virginica and is now also considered a pest on commercial oyster beds in the United Kingdom, France, and elsewhere (Blanchard 1997, Barton \& Heard 2005).

The transfer of bivalves is also a well-known vector for macroalgae introductions (Critchley \& Dijkema 1984, Rueness 1989, Neushul et al. 1992, Wallentinus 2002, Ribera Siguan 2003, Mineur et al. 2004). In eastern Canada, the green algae Codium fragile ssp. tomentosoides (van Goor) (hereafter, Codium) is one such species. Codium is thought to have originally been transferred to north-eastern North America via oyster culture (Malinowski \& Ramus 1973) and to Atlantic Canada with shellfish from the United States (Campbell 1997). Bivalves on which Codium grows are often dislodged because of the increased drag they impart unto the animals (Trowbridge 1998). The alga has also been shown to smother blue mussels and bay scallops in eastern North America by attaching to the valves of the animals and keeping them shut (Fralick 1970, cited in Trowbridge 1998) and may also render afflicted bivalves more susceptible to predation (Ramus 1971). Afflicted bivalves may also have lower meat yields (Galtsoff 1964, cited in Trowbridge 1998) and presumably growth rates. Thus, it is a concern for bivalve culture operations.

Hanisak (1979) suggests that Codium may be nitrogenlimited for a good part of the growing season. Bivalves increase the concentration of nitrogen-based compounds in the water directly through excretion and indirectly through the mineralization of settled pseudofeces and feces in the surrounding sediments (e.g., Prins et al. 1998), this being particularly true in aquaculture situations (Dame 1993). Thus, it is reasonable to predict that association with bivalves in culture may increase the growth and productivity of macroalgae in some sort of cascading effect. This has also been suggested for the endemic brown algae Pilayella littoralis (Linnaeus) growing on mussels and equipment in Nova Scotia. It was shown to grow quicker on mussel lines than on control mussel lines with dead mussels (Lawrence et al. 2000).

In Europe, exotic macroalgae are also commonly associated with bivalve culture sites. In fact, Wallentinus (2002) suggests that bivalve stock transfer is the single greatest vector for exotic macroalgae in Europe. For example, Verlaque (2001) has reported 45 species of exotic macroalgae from Thau lagoon in southern France, many of which were suggested to have been introduced with or are associated with the intensive bivalve (mostly oyster, some mussel) culture there. Of these, all but 2 have a likely Pacific origin and Verlaque (2001) suggests that most of these probably arrived with imported $C$. gigas. Similar claims were also made by Maggs and Stegenga (1999), who suggest that most species of exotic red algae in the North Sea were introduced via oyster culture. Critchley and Dijkema (1984) suggest that one of the most invasive species of algae in Europe at this time, Sargassum muticum (Yendo), is believed to have been introduced with $C$. gigas and, although believed to be spread secondarily by floating thalli, has also been observed growing on $O$. edulis. A similar case has been made for the introduced algae Undaria pinnatifida (Harvey) Suringar in the Mediterranean where both shipping and oyster cultivation are believed to have aided in spreading the alga from Thau Lagoon where it was originally introduced to Europe with C. gigas spat (see Curiel et al. 2001).
All the species associated with bivalve culture discussed above may also influence the surrounding ecosystem, particularly if they occur in large numbers or high biomass. However, the importance of these different exotics on the surrounding ecosystem is not well established and requires further investigation. Further, when studied, they have usually been considered as a part of the surrounding ecosystem, not as an influence on it (for tunicates that have invaded PEI, see Osman \& Whitlatch 1995a, Osman \& Whitlatch 1995b, Osman \& Whitlatch 1995c, Stachowicz et al. 1999; Stachowicz et al. 2002; Osman \& Whitlatch 2004), although there have been some exceptions (for the same tunicates, see Whitlatch et al. 1995, Bullard et al. 2005, Getchis 2005).

When studied, the influence of hitchhikers on ecosystem functioning has at times been found to be considerable. For example, Cloern (1982) suggests that, together, the populations of three exotic bivalve species (Venerupis philippinarum Adams and Reeve, Gemma gemma Totten, and Musculista senhousia Benson) that arrived with oyster introductions (Carlton 1992a) may filter the entire volume of water of South San Francisco Bay within one day. Similarly, the slipper limpet ( $C$. fornicata), originally introduced into England with $C$. virginica, has had dramatic impacts on some benthic communities in Europe, particularly in France (see review by Goulletquer et al. 2002). The slipper limpet has been suggested to increase spatial competition, alter habitat and limit recruitment, thus displacing important commercial bivalves, such as the great scallop (Pecten maximus Linnaeus) in some areas (Chauvaud et al. 2003), but has had little effect in others (De Montaudouin et al. 2001).

\section{Exotic Toxic and Nuisance Phytoplankton}

Although the documentation of introduced phytoplankton is largely associated with introductions from ballast water (Simard \& Hardy 2004), the importance of shellfish introductions in the introduction and spread of phytoplankton that cause harmful algal blooms and other detrimental ecosystem effects is now being recognized (Kaiser \& Beadman 2002). A number of experimental studies have shown that phytoplankton may be transported via the transfer and introduction of bivalves for aquaculture. Although any stage may be transferred, the concern may be greatest for the resting stages (spores and cysts) because these are the most robust.

Toxic and other nuisance phytoplankton may be transferred with water or as cysts or other resting stages in sediments in bivalve transfers and on the external surfaces of bivalves (Minchin 1996). In one study, O’Mahony (1993) identified 67 species of phytoplankton associated with oysters transferred from France to Ireland. As was suggested above for macroalgae, there may be some feedback whereby excretory products from mussels in culture stimulate the growth of associated phytoplankton. Following a diarrhetic shellfish poisoning (DSP) outbreak, Levasseur et al. (2003) studied the abundance of the dinoflagellate Prorocentrum lima (Ehrenberg) Dodge, the presumptive causative species for the observed DSP, associated with mussel socks in the Magdalen Islands, eastern Canada. They found this species and a further previously unobserved congener, Prorocentrum mexicanum (Tafall), associated with the epibionts growing on the socks and in the guts of the mussels. Both these studies show that toxic and other nuisance phytoplankton may live associated with epibionts of cultured 
mussels and thus may be transferred along with them during stock transfers. For example, Lawrence et al. (2000) studied the relationship between macroalgae and mussel farming and found the DSP-related dinoflagellate $P$. lima growing associated with $P$. littoralis growing on mussels and equipment in Nova Scotia.

A number of studies have shown that phytoplankton may also be carried within bivalves during stock transfers (Bricelj \& Shumway 1998). Laing and Gollasch (2002) discuss how the nuisance diatom Coscinodiscus wailesii (Gran \& Angst) may have arrived in Europe with bivalve importations, possibly having been transported within the gut or pseudofaeces of oysters in the form of resting cells. This has also been suggested as a possible vector for the exotic toxic dinflagellate Alexandrium catenella (Whedon \& Kofoid) Balech, which is now found in Thau Lagoon (Lilly et al. 2002, Penna et al. 2005). Penna et al. (2005) further suggest that even if bivalve transfers for aquaculture are not the initial vector for harmful phytoplankton species, they may be for secondary spread. Similarly, Tsujino et al. (2002) found abundant viable cysts of the toxic dinoflagellate Alexandrium spp. in bivalve faecal pellets in Japan, suggesting that this genus may also be transferred with bivalves for aquaculture purposes. This was further supported by work by Bricelj et al. (1993) that showed that M. edulis feces can contain viable Alexandrium fundyense (Balech) cells and Hallegraeff (1993) has reported resistant resting stages from the digestive tracts of bivalves. Following an outbreak of paralytic shellfish poisoning, the potentially toxin-producing dinoflagellates Gonyaulax excavata (Braarud) Balech (=Alexandrium tamarense) and Prorocentrum minimum (Pavillard) Schiller were found on the gills and in the digestive tract of mussels from areas where the suspect mussels originated (Langeland et al. 1984). Scarratt et al. (1993) did an experiment to determine the potential of $A$. tamarense being transferred with scallop (Placopecten magellanicus Gmelin) and M. edulis spat. They showed that live cells were released from the bivalves after spending $6 \mathrm{~h}$ under simulated transfer conditions. Similarly, Imada et al. (2001) demonstrated that the spread of the harmful dinoflagellate, Heterocapsa circularisquama Horiguchi, could be facilitated by the transfer of shellfish stock between areas after immotile cells were found to be viable after simulated stock transfers. Subsequent work has shown how these and other species of phytoplankton may all pass through a variety of bivalve species and remain viable (Laabir \& Gentien 1999, Bauder \& Cembella 2000, Harper et al. 2002, Springer et al. 2002, Hégaret et al. 2006), highlighting the possibility of introducing toxic or otherwise harmful phytoplankton with bivalve transfers.

\section{Exotic Parasites and Disease-causing Organisms}

Diseases in many species of bivalves in culture and in fisheries are well known throughout the world (Harvell et al. 1999, see also the special issue on bivalve diseases in Aquatic Living Resources 17(4) 2004). Figueras (2004: 395) pointed out that, "bivalve diseases are one of the critical bottle necks causing important and recurrent losses in bivalve culture." Thus, with respect to diseases of oysters, Ruesink et al. (2005) suggest that introductions and transfers have been a major cause of emerging diseases and Farley (1992) suggests that most mass mortalities have resulted from the transfer of infected stock. Indeed, it has been suggested that one of the more infamous bivalve diseases in Canadian history, the outbreak of Malpeque Bay disease in oysters in Prince Edward Island in 1915, resulted from a transfer of $C$. virginica stock from New England (Barber 1996). That being said, many diseases have only recently been described, are cryptic and may not become expressed once an introduction has taken place (Minchin 1996). In general, species of concern fall into one of 4 main taxa: viruses, bacteria, protozoans, and higher invertebrates. Good general reviews of the main species are available in Bower et al. (1994) and Bower and McGladdery (2003) give a more in-depth discussion on all the major species. Good reviews for pathogens of oysters and their effects may be found in Shatkin et al. (1997), National Research Council (2004), and Ruesink et al. (2005).

\section{MANAGEMENT ISSUES}

From the previously mentioned facts, it is clear that the introduction and transfer of bivalves for aquaculture purposes has been a major source of introduction of exotic species. Although not explicitly studied, it is also clear that such introductions may have profound effects on bivalve culture itself and also on the receiving ecosystems. It is also evident that once established, exotic species are rarely eliminated from their new habitat (Mack et al. 2000). Thus, exotic species must be checked before they arrive in a new area. Appropriate governance must be established to ensure that risks of introductions are minimized. Minchin and Rosenthal (2002) identify the 1960 s as the period when uncontrolled introduction or transfers of aquaculture products were seriously questioned. The development of the International Council for the Exploration of the Sea (ICES) Code of Practice on the Introductions and Transfers of Marine Organisms (hereafter referred to as the "ICES Code") protocols (first advanced in 1973 and revised numerous times subsequently) initially proposed a mechanism whereby the risks associated with the introductions of new species could be minimized based upon quarantine measures. Subsequent revisions of the protocols provide advice on assessing the risks of introducing hitchhiker species and genetic consequences of an introduction even within the context of routine movements of aquaculture species (ICES 2005).

\section{Risk Assessment}

Risk analysis is an important tool in designing and justifying regulatory actions in the international market place. For example, the Office International des Epizootic (OIE) manual for disease control uses risk analysis as the basis for justifying restrictions on movement of aquatic animals in response to concerns about disease transfer and control. Their intent is to provide guidelines and principles for conducting transparent, objective and defensible risk analyses for international trade. Furthermore, ICES have embraced this approach is recent revisions of the ICES Code. The United Nations Group of Experts on the Scientific Aspects of Marine Protection (GESAMP) identified the risks associated with the escapes or establishment of aquaculture species in the wild as a subject area where improved systems and advice were required. A joint project between GESAMP Working Group 31 on Environmental Impacts of Coastal Aquaculture and the International Council for the Exploration of the Sea (ICES) Working Group on Environmental Interactions of Mariculture (WGEIM) was 
initiated to develop improved risk analysis procedures to assist stakeholders in the coastal zone to come to decisions regarding coastal aquaculture proposals. These endeavors have resulted in a general template for conducting risk analysis relating to aquaculture activities as well as a series of case studies (ICES 2006). In European Union member states, the adoption of the "Council Regulation Concerning the use of Alien and Locally Absent Species in Aquaculture" will enshrine, in law, risk analysis approaches developed for introductions in aquaculture that were, heretofore, largely voluntary (i.e., the ICES Code).

To minimize impacts relating to shellfish introductions and transfers, it is necessary to carry out an appropriate risk assessment in advance of any proposed stock transfers or introductions (Rosenfield 1992, Minchin 1996, Minchin \& Rosenthal 2002, Wolff \& Reise 2002, Forrest et al. 2004, National Research Council 2004, ICES 2005, Ruesink et al. 2005, Hewitt et al. 2006). Several case studies are available (highlighted earlier and ICES 1995, National Research Council 2004, Ruesink et al. 2005, Wijsman \& Smaal 2006) that show the process fairly well and a more general risk analysis process for aquatic organisms is outlined by Orr (2003). It must be noted that these case studies are all relatively recent and represent the seriousness with which proponents are now considering the ecological risks associated with the movement of species for use in aquaculture. The ICES Code presents a flowchart to follow, the goal of which is to minimize the chances of introductions and ecological damage. The following is summarized from Ruesink et al. (2005) and ICES (2005) and emphasizes the need for 4 main steps in the risk assessment and a fifth to reduce risks associated with direct introduction of stock from one location to another:

1. An extensive understanding of the functioning of the receiving ecosystem (predator-prey interactions, competition, diseases, environmental responses, etc.) and of the basic requirements of the target bivalve species. Use this information for steps 2-4, later.

2. Determine the probability of (i) colonization and establishment of the target bivalve species in the target area and (ii) the potential for the bivalve to spread.

3. Estimate the effect of the introduction of the target bivalve species on the receiving ecosystem, including trophic interactions, habitat transformations, and interactions with native species of concern (threatened or declining).

4. Estimate the probability of transferring/establishing a pathogen or parasite or other deleterious organism into the receiving ecosystem. Although not explicit in the Code, this step should also include any potential effects of all possible hitchhiking species.

5. Establish quarantine and disinfection protocols to help prevent the introduction of undesirable hitchhikers, possibly with the release of only proven uncontaminated progeny into the environment, and the development of a contingency plan to withdraw the species should this become necessary.

It should be highlighted that the complete information required in step 1 is rarely available. That being said, the identification of crucial knowledge gaps in this step is important in guiding future research. A case in point is the number of studies that have been derived from the risk assessment carried out by the National Academy of Science (NRC 2004) on the proposed introduction of nonnative oysters in the Chesapeake
Bay, USA. Indeed, some evidence suggests that the utilization of such assessments can help curb the influx of exotic species in a given area. Prior to 1960, the ecological implications of large-scale introductions of exotic bivalves were largely ignored; transfers, and the like occurred without much foresight (Wolff \& Reise 2002). Since then, many codes of practice have been implemented with respect to shipping, bivalve transfers, and the like, and there has been a concomitant decrease in the rate of exotic species introductions, at least in Europe (Streftaris et al. 2005). Transfers are thus less important to the introduction of novel species today but are still important on a regional scale both within Europe (Wolff \& Reise 2002) and eastern Canada (Bourque et al. 2003). In contrast, unwanted introductions may occur when such logic is not followed. A good example of this concerns Mytilicola orientalis (Mori), a parasitic copepod from Japan that occurs in the lower intestine of oysters and mussels. Britain and Ireland were initially free of the parasite because of historic quarantines for $C$. gigas. However, a prohibition on the introduction of half grown oysters was deemed to be a contravention of an EU free trade directive (Council Directive 91/67/EEC of 28 January 1991 concerning the animal health conditions governing the placing on the market of aquaculture animals and products). Consequently, half-grown oysters were transferred from France to Ireland, which led to the introduction of this parasite and others and a variety of other exotic species (Minchin et al. 1993, O’Mahony 1993, Minchin 1996, see also Minchin \& Rosenthal 2002 for other impacts of the EU directive).

\section{Caveats With Respect to Spread and Predictions of Ecological Effects}

Predictions of the risk of spread and ecological effects of introduced bivalve species for aquaculture are only as good as the information available to predict them. Although the requirements of the bivalves being introduced are usually fairly well known, this is not always the case. Novel interactions within a new environment may further limit the accuracy of predictions based solely on information from elsewhere. For example, although the $C$. gigas culture industry in Tasmania and South Australia, Australia, is entirely based on hatcheryraised seed, the species has been declared a "noxious fish" on the Australian mainland in most of New South Wales, where it has escaped from the hatchery-based system and spread, affecting the locally important Sydney rock oyster (Saccostrea commercialis Iredale and Roughley) industry (Shatkin et al. 1997). Similarly, at the time of the introduction of C. gigas to the Netherlands, conventional wisdom dictated that local environmental conditions would not allow Pacific oysters to successfully reproduce (described in Dijkema 1997). Not only has the species acclimatized to conditions in the Netherlands, its coverage has increased from 15 hectares in 1985 to 750 ha in 2005 in the Oosterschelde (Smaal et al. 2005) and is now considered a serious nuisance to traditional mussel aquaculture practices.

Similar caveats with respect to the ecological effects of introductions on the receiving ecosystem are at least as important. In general, knowledge of the functioning of the receiving ecosystems is extremely limited. For example, knowledge of the interactions among the endemic roughly equivalent (to the target bivalve) species and their main competitors and predators, as well as its associated fauna and the rest of the ecosystem is commonly lacking. Thus predictions of interactions of any 
new member of the community are necessarily based largely on studies from elsewhere and general ecological principles. Even when the information is available, novel interactions are likely to arise that could not be predicted, even with the best information and foresight. The case of M. galloprovicialis in South Africa is a good example. The intertidal ecology and biodiversity on the west coast of the country, where M. galloprovicialis is spreading (McQuaid and Phillips 2000), are very well studied and understood (Branch \& Steffani 2004). The area is characterized by high biomass and relatively low species diversity (Bustamante \& Branch 1996) and intense upwellings create strong gradients in productivity along the coast (Bustamante et al. 1995). Consequently, Branch and Steffani (2004) were able to predict the spread and effect of the introduction of $M$. galloprovicialis at a variety of levels of complexity of the ecosystem. However, there was no way of predicting that the establishment of $M$. galloprovicialis would lead to mass mortalities of Ovalipes trimaculatus (De Haan), a mobile burying predatory crab, in the surf zone of sandy beaches. Apparently $M$. galloprovicialis spat settle on the eyestocks and mouthparts of the crab, which are the only hard substrate in that particular ecotype, effectively killing the animal. Some interactions simply cannot be predicted and any introduction may have some unforeseen effects.

The effects of hitchhiking species are even more complex as most are typically poorly studied and thus their roles in any new environment are even harder to predict. To use a recurring example, the suite of tunicates currently creating problems in PEI seems to have become a fairly unassuming part of the ecosystem in the central part of the New England states according to the ecological literature (see above). However, it appears that their influence in bivalve culture sites in the same general region (Bullard et al. 2005, Getchis 2005) and PEI is not so benign. This may be because many embayments in New England (Altieri \& Witman 2006) and PEI (Meeuwig et al. 1998) are hyper-eutrophic because of catchment basin land-use patterns. A number of authors have suggested a link between disturbance in the form of eutrophication and the susceptibility of a system to invasion by exotic species (Ruiz et al. 1999, Ruiz et al. 2000) Indeed, invasive species have been found to outcompete native species or fill vacant niches (see Herbold \& Moyle 1986) under such conditions. Examples may be found for macrophytes (Bertness et al. 2002), algae (Wikström \& Kautsky 2004), phytoplankton (Smayda \& Reynolds 2001) and invertebrates (Currie et al. 2000). There has also been the suggestion that another invasive species, the green crab, may facilitate at least one of these tunicates by consuming a gastropod predator that might limit the establishment of S. clava (Locke et al. 2007). These factors interact in myriad ways to modify ecosystem processes and communities. However, most of these interactions are only theoretical and have been little studied (Cloern 2001). Whatever the cause, the fact that exotic tunicate species become nuisance species in some bivalve culture areas but not in other parts of the same ecosystem underlies the point that prediction of impacts may not be made simply by comparing similar situations.

\section{Quarantine, Disinfection and Other Protocols to Limit Risk}

A number of ideas to prevent the spread of the target bivalves have been discussed (Shatkin et al. 1997, National
Research Council 2004) The simplest is to select species that cannot complete their lifecycles in the receiving environment so that the industry will be dependent upon hatcheries (however, see examples of $C$. gigas in the Netherlands and Germany above). Although this approach has a certain simple appeal, such a species may also not be particularly well adapted for the grow-out environment in other ways and thus may not be the optimal species for the industry. The idea that a target species may be limited to a small geographical area because of particular environmental conditions also has problems. First, if it thrives there, then other vectors (Ruiz \& Carlton 2003) become important and secondary spread outside of the original point of introduction is possible, even if the species may not complete its lifecycle within the culture site (National Research Council 2004). More intrusive methods, including polyploidy and genetic modification to produce essentially sterile individuals, have also been suggested. Although polyploidy is feasible in a hatchery situation, all individuals are not affected (Shatkin et al. 1997) and some polyploidy individuals may revert to a normal diploid condition (e.g., McCombie et al. 2005) thus the risk of spread, although reduced, is not eliminated.

If introduction is deemed acceptable, as outlined above, one of the first lines of defense to limit the introduction of exotic species with aquaculture practices should be to establish quarantine and/or disinfection protocols. The first choice for introductions should be to use hatchery-raised and tested stock grown in "clean" areas (Minchin \& Rosenthal 2002). However, this is not always feasible in day-to-day operations of bivalve culture sites as stock is often relayed among sites at a regional scale. Thus, actions must be taken to limit the risk of transferring hitchhikers along with the stock and/or limit their spread in the environment. As pointed out by Buhle et al. (2005), very different methods may be appropriate for different life stages and cost-effectiveness studies may minimize the cost of an overall management strategy.

A number of treatments to minimize the impacts of tunicates on shellfish culture operations have been evaluated around the world. These including treating the mussel lines and equipment used in the culture operations by either dipping them in or spraying them with acetic and other acids, brine or lime solutions or fresh water or else using high-pressure sprays, drying, heat, and the like (Boothroyd et al. 2002, Anonymous 2003, Bourque et al. 2003, Carver et al. 2003, Forrest et al. 2004, Mineur et al. 2004; Thompson \& MacNair 2004, MacDonald et al. 2005, Swan et al. 2005). To date, different producers have used different management strategies with lesser or greater degrees of success. For example, Mineur et al. (2004) examined the efficacy of using pressure washing to clean oysters in an experiment that simulated "normal" operational culture conditions. After washing, the oysters were then incubated for $40 \mathrm{~d}$ under laboratory conditions with a clean water source, after which time about 20 species of algae were observed to be growing on the oyster shells, including a few exotic species found only in that culture site so far. Minchin and Rosenthal (2002) discuss how a shipment of $C$. gigas from Japan to France led to the introduction of a number of species into Europe, despite the fact that, upon arriving in France, the oysters were subjected to a brine dip to kill the organisms attached to their shells. Shatkin et al. (1997) outline how similar transfers from Japan and British Columbia to France that had been treated with freshwater baths 
and inspected led to the establishment of a number of species, including barnacles and algae that were stuck to the outside of the oysters. In short, disinfection of bivalves for external hitchhikers is not always effective and must be weighted against the potential environmental impacts of any treatment. Although the use of biological control measures (using other species, usually diseases or predators, to limit the presence of a target species) has been discussed for some time (see Lafferty \& Kuris 1996; Messing \& Wright 2006), to our knowledge, few attempts of this have been tried. That being said, an experiment was done in PEI recently to examine the efficacy of a biological control measure to reduce the abundance of $C$. intestinalis on mussel lines. This was done by sinking the lines to the bottom and supplementing the local population the indigenous rock crab $C$. irroratus, a predator of the tunicate, with individuals fished elsewhere. Results to date seem promising (Landry, pers. observ.).

The use of dips and the like does not address the problem of introducing organisms that live within living bivalves or the shells of dead ones and thus most parasites, bacteria, viruses, and protozoan diseases as well as some phytoplankton will not be addressed using these methods (Minchin 1996). The alternative here is to use depuration so that the target bivalves can clear themselves of the organisms of concern. Although longused to purge bivalves of toxins associated with, among various factors, toxic phytoplankton and for coliforms and other noxious human-associated microbes (Otwell et al. 1991, Sekiguchi et al. 2001, Blanco et al. 2002, Lee \& Younger 2002), such an approach has also been shown possible for toxic phytoplankton themselves (Scarratt et al. 1993, Dijkema 1995, cited in Kaiser \& Beadman 2002). However, efficacy is both bivalve- and phytoplankton species-dependent (Hégaret et al. 2006). Recent work by Bushek et al. (2004) has also shown that depuration or quarantine of shucked oyster shells prior to use as oyster cultch is important to limit the potential spread of the protozoan parasite Perkinsus marinus (Mackin, Owen \& Collier) among regions. Depuration will not however work for organisms that are not released by bivalves over time. This includes many parasites, bacteria, and other bivalverelated pathogens. In these instances, quarantine and growth of $F_{1}$ individuals for introduction is prescribed (Minchin \& Rosenthal 2002). This approach is also however ineffective for vertically transmitted pathogens. Barber (1996) gives an example of how a protozoan parasite, Perkinsus karlssoni, persisted for 10 generations in quarantined Argopecten irradians (Lamarck) populations. Further, any monitoring to see if stock is "clean" is only as good as the test used for monitoring (Carnegie et al. 2003) and hitherto unknown species that are only expressed once in a new environment cannot be detected (Minchin 1996).

The efficacy of the above protocols to limit risk is obviously a function of how well any guidelines are followed. As pointed out by Minchin and Rosenthal (2002), unauthorized transfers and introductions of bivalves are serious issues that pose risks to future bivalve production and ecosystem integrity. They (Minchin \& Rosenthal 2002) give an international (United
States to Ireland) example but the same issues exist at regional scales where bivalves are transported among sites for grow-out or relaying (Wasson et al. 2001).

\section{CONCLUSION}

It is clear that exotic species of bivalves used in aquaculture and other associated species associated with bivalve aquaculture may have important ecological and economic effects. Thus effective management must be used to limit the risks associated with exotic species in aquaculture. To this end, risk analysis has been and should continue to be used to inform these management decisions and to identify knowledge gaps with respect to exotic species in bivalve culture (the cultured bivalves themselves and hitchhiking species). Recent EU legislation has been a positive step towards this end. Although much of the information required to carry out a fully informed risk assessment will often be unavailable, the steps outlined in the risk assessment should nevertheless be completed to the extent possible to both derive an unbiased view of the situation and thus make appropriate management decisions as well as to identify knowledge gaps that should be addressed with directed research, ideally prior to the introduction of bivalves into a system for aquaculture.

In summary, it is apparent that to carry out meaningful risk assessments a number of general areas of research need be addressed: (1) to predict the ability of exotic bivalves to establish and spread in the receiving environment; (2) to predict the impact of exotic bivalves on receiving ecosystems, including interactions with local species, habitat modifications, energy flow, and the like; (3) to identify potential hitchhiker species likely to accompany culture organisms; (4) to better understand the requirements and influence of hitchhiking species in the environment; (5) to better understand the relative importance of natural (currents, dispersion rates, and the like) and anthropogenic (culture species as habitat/substrate providers, stock transfers, processing, hull fouling, and the like) spread of exotic species; (6) to develop remedial measures to mitigate impacts and minimize spread; (7) to better understand the links between the presence of exotic species and other stressors in the environment (e.g., eutrophication, climate change, fishing activities, contamination, and so on).

\section{ACKNOWLEDGMENTS}

The core of this paper was developed during the 2006 ICES Working Group on Environmental Interactions of Mariculture (WGEIM) workshop that was held in Narragansett, Rhode Island, United States, in April 2006. Previous version appeared in the proceedings of that workshop (http://www.ices.dk/ reports/MCC/2006/wgeim06.pdf) and as a Canadian Technical Report of Fisheries and Aquatic Sciences. The authors thank the WGEIM and 3 anonymous reviewers for reviewing earlier versions of this paper.

\section{LITERATURE CITED}

Altieri, A. H. \& J. D. Witman. 2006. Local extinction of a foundation species in a hypoxic estuary: integrating individuals to ecosystem. Ecology. 87:717-730.
Anderson, M. R., P. Cranford, C. W. McKindsey, P. Strain, B. T. Hargrave, W. K. W. Li \& W. G. Harrison. 2006. Cumulative and far-field fish habitat effects. DFO Can. Sci. Advis. Sec. Res. Doc. 2006/037: vii + 30 p. 
Anonymous. 2003. Clubbed tunicate use options. Prince Edward Island Agriculture, Fisheries and Aquaculture Technical Report 232: iv + $30 \mathrm{p}$.

Balon, E. K. 1995. Origin and domestication of the wild carp, Cyprinus carpio: from Roman gourmets to the swimming flowers. Aquaculture. 129:3-48.

Barber, B. J. 1996. Impacts of Shellfish introductions on local communities. In: J. Pedersen, editor. Exotic species workshop: issues relating to aquaculture and biodiversity. Cambridge: MIT Sea Grant College Program (MITSG 96-15). pp. 18-21.

Bartol, I. \& R. Mann. 1997. Small-scale settlement patterns of the oyster Crassostrea virginica on a constructed intertidal reef. Bull. Mar. Sci. 61:881-897.

Barton, E. \& J. Heard. 2005. The Marine Biological Association of the United Kingdom and The Marine Life Information Network for Britain and Ireland, http://www.marlin.ac.uk/PDF/MLTN_ alien_non_natives.pdf

Bauder, A.G. \& A.D. Cembella. 2000. Viability of the toxic dinoflagellate Prorocentrum lima following ingestion and gut passage in the bay scallop Argopecten irradians. J. Shellfish Res. 19:321324

Beadman, H. A., R. I. Willows \& M. J. Kaiser. 2002. Potential applications of mussel modelling. Helgol. Mar. Res. 56:76-85.

Behrens Yamada, S. 2001. Global invader: the European green crab. Corvalis: Oregon Sea Grant. 123 pp.

Bertness, M. D., P. J. Ewanchuk \& B. R. Silliman. 2002. Anthropogenic modification of New England salt marsh landscapes. Proc. Natl. Acad. Sci. USA. 99:1395-1398.

Blanchard, M. 1997. Spread of the slipper limpet Crepidula fornicata (L.1758) in Europe. Current state and consequences. Sci. Mar. 61:109-118.

Blanco, J., C. P. Acosta, M. B. de la Puente \& C. Salgado. 2002. Depuration and anatomical distribution of the amnesic shellfish poisoning (ASP) toxin domoic acid in the king scallop Pecten maximus. Aquat. Toxicol. 60:111-121.

Boghen, A. D. 1995. Cold-water aquaculture in Atlantic Canada. Moncton: Canadian Institute for Research on Regional Development. xiii $+672 \mathrm{pp}$.

Boothroyd, F. A., N. G. MacNair, T. Landry, A. Locke \& T. J. Davidson. 2002. Dealing with an aquatic invader: the clubbed tunicate (Styela clava) in Prince Edward Island waters. In: Aquaculture Canada 2002. Charlottetown, PEI.

Bourne, N. 1979. Pacific oysters, Crassostrea gigas Thunberg, in British Columbia and the South Pacific Islands. In: R. Mann, editor. Exotic Species in Mariculture. Cambridge: MIT Press. pp. 1-53.

Bourque, D., T. Landry, J. Davidson \& N. McNair. 2003. Impact of an invasive tunicate in Atlantic Canada: Recruitment and competition. J. Shellfish Res. 22:320.

Bourque, D., A. LeBlanc \& T. Landry. 2003. Inter-specific competition between an invasive filter-feeding tunicate (Styela clava) and cultivated mussels (Mytilus edulis) in Prince Edward Island, Canada. In: Aquaculture Canada 2003. Victoria, BC.

Bower, S. M. \& S. E. McGladdery. 2003. Synopsis of infectious diseases and parasites of commercially exploited shellfish. In: http:// www.pac.dfo-mpo.gc.ca/sci/shelldis/title_e.htm.

Bower, S. M., S. E. McGladdery \& I. M. Price. 1994. Synopsis of infectious diseases and parasites of commercially exploited shellfish. Ann. Rev. Fish Dis. 4:1-199.

Branch, G. M. \& C. N. Steffani. 2004. Can we predict the effects of alien species? A case-history of the invasion of South Africa by Mytilus galloprovincialis (Lamarck). J. Exp. Mar. Biol. Ecol. 300:189215.

Bricelj, V. M., M. Greene \& A. D. Cembella. 1993. Growth of the blue mussel Mytilus edulis on toxic Alexandrium fundyense and effects of gut passage on dinoflagellate cells. In: T. J. Smayda \& Y. Shimizu, editors. Toxic Phytoplankton Blooms in the Sea. New York: Elsevier. pp. 371-376.
Bricelj, V. M. \& S. E. Shumway. 1998. Paralytic shellfish toxins in bivalve molluscs: occurrence, transfer kinetics, and biotransformation. Rev. Fish. Sci. 6:315-383.

Broekhuizen, N., J. Zeldis, S.A. Stephens, J.W. Oldman, A.H. Ross, J. Ren \& M. R. James. 2002. Factors related to the sustainability of shellfish aquaculture operations in the Firth of Thames: a preliminary analysis. Hamilton, New Zealand. NIWA Client Report EVW02243: vi $+106 \mathrm{p}$.

Bruno, J. F. \& M. D. Bertness. 2001. Habitat modification and facilitation in benthic marine communities. In: M. D. Bertness, S. D. Gaines \& M. E. Hay, editors. Marine community ecology. Sunderland: Sinauer Associates, Inc. pp. 201-218.

Buhle, E. R., M. M. Margolis \& J. L. Ruesink. 2005. Bang for buck: cost-effective control of invasive species with different life histories. Ecol. Econ. 52:355-366.

Bullard, S., R. B. Whitlatch, S. E. Shumway \& R. W. Osman. 2005. Scientists crying foul: sea squirts are invading Long Island Sound! Wrack Lines 5:2-6.

Bushek, D., D. Richardson, M. Y. Bobo \& L. D. Coen. 2004. Quarantine of oyster shell cultch reduces the abundance of Perkinsus marinus. J. Shellfish Res. 23:369-373.

Bustamante, R. H. \& G. M. Branch. 1996. Large scale patterns and trophic structure of southern African shores: the roles of geographic variation and wave exposure. J. Biogeogr. 23:339351.

Bustamante, R. H., G. M. Branch, S. Eekhout, B. Robertson, P. Zoutendyk, M. Schleyer, A. Dye, N. Hanekom, D. Keats, M. Jurd \& C. McQuaid. 1995. Gradients of intertidal primary productivity around the coast of South Africa and their relationships with consumer biomass. Oecologia 102:189-201.

Campbell, M. 1997. National report for Canada. In: ICES Advisory Committee on the Marine Environment, editor. Report of the working group on introductions and transfers of marine organisms (WGITMO), ICES CM 2000/ACME: 07. pp. 24-30.

Carbines, G. D. 1993. The ecology and early life history of Notolabrus celidotus (Pisces: Labridae) around mussel farms in the Marlborough Sounds. MSc thesis, University of Canterbury, Christchurch, pp 134.

Carlton, J. T. 1989. Man's role in changing the face of the ocean: biological invasions and implications for conservation of near-shore environments. Conserv. Biol. 3:265-273.

Carlton, J. T. 1992a. Introduced marine and estuarine mollusks of North America: an end-of-the-20th-century perspective. J. Shellfish Res. 11:489-505.

Carlton, J. T. 1992b. Dispersal of living organisms into aquatic ecosystems as mediated by aquaculture and fisheries activities. In: A. Rosenfield \& R. Mann, editors. Dispersal of living organisms into aquatic ecosystems. College Park: Maryland Sea Grant. pp. 13-46.

Carlton, J. T. 1999. Molluscan invasions in marine and estuarine communities. Malacologia. 41:439-454.

Carlton, J. T. \& R. Mann. 1996. Transfers and world-wide introductions. In: V. S. Kennedy, R. I. E. Newell \& A. F. Eble, editors. The Eastern Oyster Crassostrea virginica. College Park: Maryland Sea Grant. pp. 691-706.

Carnegie, R. B., B. J. Barber \& D. L. Distel. 2003. Detection of the oyster parasite Bonamia ostreae by fluorescent in situ hybridization. Dis. Aquat. Org. 55:247-252.

Carver, C. E., A. Chisholm \& A. Mallet. 2003. Strategies to mitigate the impact of Ciona intestinalis (L.) biofouling on shellfish production. J. Shellfish Res. 22:621-631.

Castel, J., P. J. Labourg, V. Escaravage, I. Auby \& M. E. Garcia. 1989 Influence of seagrass beds and oyster parks on the abundance and biomass patterns of meio- and macrobenthos in tidal flats. Estuar. Coast. Shelf Sci. 28:71-85.

Chauvaud, L., G. Thouzeau, J. Grall \& Y. M. Paulet. 2003. Exploitation et surexploitation des ressources marines vivantes, \#17: La 
crepidule en rade de Brest: un paradoxe pour le devenir de la coquille Saint-Jacques. Rapp. Sci. Technol. Acad. Sci. Paris 17:307-318.

Chew, K. K. 1990. Global bivalve shellish introductions. World Aquacult. 21:9-22.

Cloern, J. E. 1982. Does the benthos control phytoplankton biomass in south San Francisco Bay? Mar. Ecol. Prog. Ser. 9:191-202.

Cloern, J. E. 2001. Our evolving conceptual model of the coastal eutrophication problem. Mar. Ecol. Prog. Ser. 210:223-253.

Cook, E., K. Willis \& G. Ashton. 2004. Population dynamics and development of an invasive caprellid amphipod-Caprella mutica. In: 13th International Conference on Aquatic Invasive Species. Ireland. p. 59.

Cox, G. W. 2004. Alien species and evolution: the evolutionary ecology of exotic plants, animals, microbes, and interacting native species. Washington: Island Press. 377 pp.

Critchley, A. T. \& R. Dijkema. 1984. On the presence of the introduced brown alga Sargassum muticum, attached to commercially imported Ostrea edulis in the S. W. Netherlands. Bot. Mar. 27:211-216.

Crooks, J. A. 2002. Characterizing ecosystem-level consequences of biological invasions: the role of ecosystem engineers. Oikos. 97:153166.

Cuddington, K. \& A. Hastings. 2004. Invasive engineers. Ecol. Eng. 178:335-347.

Curiel, D., P. Guidetti, G. Bellemo, M. Scattolin \& M. Marzocchi. 2001. The introduced alga Undaria pinnatifida (Laminariales, Alariaceae) in the lagoon of Venice. Hydrobiologia. 477:209-219.

Currie, D. R., M. A. McArthur \& B. F. Cohen. 2000. Reproduction and distribution of the invasive European fanworm Sabella spallanzanii (Polychaeta: Sabellidae) in Port Phillip Bay, Victoria, Australia. Mar. Biol. 136:645-656.

Dame, R. F. 1993. Bivalve filter feeders in estuarine and coastal ecosystem processes. Berlin: Springer-Verlag. 579 pp.

Dame, R. F. 1996. Ecology of marine bivalves: an ecosystem approach. Boca Raton: CRC Press. 254 pp.

Dayton, P. K. 1972. Toward an understanding of community resilience and the potential effects of enrichments to the benthos at McMurdo Sound, Antarctica. In: B. C. Parker, editor. Colloquium on conservation problems in Antarctica. Blacksburg, VA. pp. 81-96.

De Montaudouin, X., D. Labarraque, K. Giraud \& G. Bachelet. 2001. Why does the introduced gastropod Crepidula fornicata fail to invade Arcachon Bay (France)? J. Mar. Biol. Ass. UK. 81:97104.

Dealteris, J. T., B. D. Kilpatrick \& R. B. Rheault. 2004. A comparative evaluation of the habitat value of shellfish aquaculture gear, submerged aquatic vegetation and a non-vegetated seabed. J. Shellfish Res. 23:867-874.

Diederich, S. 2005. Differential recruitment of introduced Pacific oysters and native mussels at the North Sea coast: coexistence possible? J. Sea Res. 53:269-281.

Diederich, S. 2006. High survival and growth rates of introduced Pacific oysters may cause restrictions on habitat use by native mussels in the Wadden Sea. J. Exp. Mar. Biol. Ecol. 328:211-227.

Dijkema, R. 1995. Large-scales recirculation systems for storage of imported bivalves as a means to counteract introduction of cysts of toxic dinoflagellates in the coastal waters of the Netherlands. In: R. Poggi \& J. Y. Le Gall, editors. 2nd Conference Internationale sur la Purification des Coquillages, Rennes (France), 6-8 April 1992: IFREMER. pp. 355-367.

Dijkema, R. 1997. Molluscan fisheries and culture in the Netherlands. In: C. L. Mackenzie, Jr., V. G. Burrell, Jr., A. Rosenfield \& W. L. Hobart, editors. The history, present condition, and future of the molluscan fisheries of North and Central America and Europe, Volume 3, Europe: NOAA Tech. Rep. 129. pp. 115-135.

Drinkwaard, A. C. 1999. Introductions and developments of oysters in the North Sea area: a review. Helgol. Meeresunters. 52:301-308.

Dumbauld, B. R., E. P. Visser, D. A. Armstrong, L. Cole-Warner, K. L. Feldman \& B. E. Kauffman. 2000. Use of oyster shell to create habitat for juvenile Dungeness crab in Washington coastal estuaries: status and prospects. J. Shellfish Res. 19:379-386.

Escapa, M., J. P. Isacch, P. Daleo, J. Alberti, O. Iribarne, M. Borges, E. P. Dos Santos, D. A. Gagliardini \& M. Lasta. 2004. The distribution and ecological effects of the introduced Pacific oyster Crassostrea gigas (Thunberg, 1793) in northern Patagonia. J. Shellfish Res. 23:765-772.

Farley, C. A. 1992. Mass mortalities and infectious lethal diseases in bivalve molluscs and associations with geographic transfers of populations. In: A. Rosenfield \& R. Mann, editors. Dispersal of living organisms into aquatic ecosystems. College Park: Maryland Sea Grant. pp. 139-154.

Figueras, A. 2004. Foreward. Aquat. Living Resour. 17:395.

Floyd, T. \& J. Williams. 2004. Impact of green crab (Carcinus maenas L.) predation on a population of soft-shell clams (Mya arenaria L.) in the southern Gulf of St. Lawrence. J. Shellfish Res. 23:457-462.

Forrest, B., T. Dodgshun \& K. Blakemore. 2004. Vector management tools for invasive marine species: reducing the spread of biofouling pests with aquaculture transfers. In: 13th International Conference on Aquatic Invasive Species. Ennis, Ireland. 159 pp.

Fralick, R. A. 1970. An ecological study of Codium fragile subsp. tomentosoides in New England. MSc thesis, University of New Hampshire, Durham.

Galtsoff, P. S. 1964. The American Oyster Crassostrea virginica Gmelin. U.S. Fish Wildl. ServiceFish. Bull. (Wash. DC.) 64:1-480.

Getchis, T. S. 2005. What's putting some aquaculturists in a "foul" mood? Fouling organisms are taking their toll on marine aquaculture. Wrack Lines 5:8-10.

Glude, J. B. 1955. The effects of temperature and predators on abundance of the soft-shell clam, Mya arenaria, in New England. Trans. Am. Fish. Soc. 84:13-26.

Gollasch, S. 2006. Overview on introduced aquatic species in European navigational and adjacent waters. Helgol. Mar. Res. 60:84-89.

Gosling, E. M. 1992. Bivalve molluscs: biology, ecology and culture. Oxford: Blackwell. 454 pp.

Goulletquer, P., G. Bachelet, P. G. Sauriau \& P. Noel. 2002. Open Atlantic coasts of Europe - a century of introduced species into French waters. In: E. Leppäkoski, S. Gollasch \& S. Olenin, editors. Invasive aquatic species of Europe: Distribution, impacts and management. Dordrecht: Kluwer Academic Publishers. pp. 276 290.

Griffiths, C. L., P. A. R. Hockey, C. Erkom Schurink \& P. J. Le Roux. 1992. Marine invasive aliens on South African shores: Implications for community structure and trophic functioning. S. Afr. J. Mar. Sci. 12:713-722.

Grizel, H. \& M. Heral. 1991. Introductions into France of the Japanese oyster (Crassostrea gigas). J. Cons. Int. Explor. Mer 47:339-403.

Guenther, J., P. C. Southgate \& R. de Nys. 2006. The effect of age and shell size on accumulation of fouling organisms on the Akoya pearl oyster Pinctada fucata (Gould). Aquaculture 253:366-373.

Hallegraeff, G. M. 1993. A review of harmful algal blooms and their apparent global increase. Phycologia 32:79-99.

Hanisak, M. D. 1979. Nitrogen limitation of Codium fragile ssp. tomentosoides as determined by tissue analysis. Mar. Biol. 50:333337.

Harper, F. M., E. A. Hatfield \& R. J. Thompson. 2002. Recirculation of dinoflagellate cysts by the mussel, Mytilus edulis L., at an aquaculture site contaminated by Alexandrium fundyense (Lebour). Balech. J. Shellfish Res. 21:471-477.

Harvell, C. D., J. M. Burkholder, R. R. Colwell, P. R. Epstein, D. J. Grimes, E. E. Hofmann, E. K. Lipp, A. D. M. E. Osterhaus, R. M. Overstreet, J. W. Porter, G. W. Smith \& G. R. Vasta. 1999. Emerging marine diseases - climate links and anthropogenic factors. Science 285:1505-1510.

Hégaret, H., S. E. Shumway, G. H. Wikfors, S. Pate \& J. M. Burkholder. 2006. Relocation of bivalve molluscs can be vectors of transport of harmful algae. In: L. E. Johnson \& M. Cusson, editors. 35th Benthic ecology meeting. Quebec City, QC. pp. 26-27. 
Heger, T. \& L. Trepl. 2003. Predicting biological invasions. Biol. Invasions 5:313-321.

Herbold, B. \& P. B. Moyle. 1986. Introduced species and vacant niches. Am. Nat. 128:751-760.

Hewitt, C. L., M. L. Campbell \& S. Gollasch. 2006. Alien species in aquaculture. Considerations for responsible use. IUCN, Gland, Switzerland and Cambridge, UK. viii $+32 \mathrm{p}$.

Hosack, G. 2003. Effects of Zostera marina and Crassostrea gigas culture on the intertidal communities of Willapa Bay, Washington. MSc thesis, University of Washington, pp vi +102.

ICES. 1995. ICES Code of practice on the introductions and transfers of marine organisms 1994. ICES co-operative research report No. 204. 19 pp.

ICES. 2005. ICES code of practice on the introductions and transfers of marine organisms 2005 . ii $+30 \mathrm{p}$.

ICES. 2006. Report of the working group on environmental interactions of mariculture. ICES, Copenhagen. iii $+195 \mathrm{p}$.

Imada, N., T. Honjo, H. Shibata, Y. Oshima, K. Nagai, K. Matsuyama \& T. Uchida. 2001. The quantities of Heterocapsa circularisquama cells transferred with shellfish consignments and the possibility of its establishment in new areas. In: G. M.. Hallegreaff, S. I.. Blackburn, C. J.. Bolch \& R. J.. Lewis, editors. Harmful algal blooms 2000. Paris: Intergovernmental oceanographic commission of UNESCO. pp. 474-476.

Iwasaki, K. 1994. Distribution and bed structure of the two intertidal mussels, Septifer virgatus (Wiegmann) and Hormomya mutabilis (Gould). Pub. Seto Mar. Biol. Lab. 36:223-247.

Iwasaki, K. 1995. Comparison of mussel bed community between two intertidal mytilids Septifier virgatus and Hormomya mutabilis. Mar. Biol. 123:109-119.

Kaiser, M. J. \& H. A. Beadman. 2002. Scoping study of the carrying capacity for bivalve cultivation in the coastal waters of Great Britain. The Crown Estate. Interim Report: 39 pp.

Khalaman, V. V. 2001. Succession of fouling communities on an artificial substrate of a mussel culture in the White Sea. Rus. J. Mar. Biol. 27:345-352.

Kott, P. 2002. A complex didemnid ascidian from Whangamata, New Zealand. J. Mar. Biol. Ass. UK. 82:625-628.

Kott, P. 2004. A new species of Didemnum (Ascidiacea, Tunicata) from the Atlantic coast of North America. Zootaxa. 732:1-10.

Laabir, M. \& P. Gentien. 1999. Survival of toxic dinoflagellates after gut passage in the Pacific oyster Crassostrea gigas Thunburg. J. Shellfish Res. 18:217-222.

Lafferty, K. D. \& A. Kuris. 1996. Biological control of marine pests. Ecology 77:1989-2000.

Laing, I. \& S. Gollasch. 2002. Coscinodiscus wailesii-a nuisance diatom in European waters. In: E. Leppäkoski, S. Gollasch \& S. Olenin, editors. Invasive aquatic species of Europe: Distribution, impacts and management. Dordrecht: Kluwer Academic Publishers. pp. 53-55.

Lambert, C. C. \& G. Lambert. 1998. Non-indigenous ascidians in southern California harbors and marinas. Mar. Biol. 130: 675-688.

Langeland, G., T. Hasselgaard, K. Tangen, O. M. Skulberg \& A. Hjelle. 1984. An outbreak of paralytic shellfish poisoning in western Norway. Sarsia 69:185-193.

Lawrence, J. E., J. Grant, M. A. Quilliam, A. G. Bauder \& A. D. Cembella. 2000. Colonization and growth of the toxic dinoflagellate Prorocentrum lima and associated fouling macroalgae on mussels in suspended culture. Mar. Ecol. Prog. Ser. 201:147-154.

LeBlanc, A. R., T. Landry \& G. Miron. 2002. Fouling organisms in a mussel cultivation bay: their effect on nutrient uptake and release. Can. Tech. Rep. Fish. Aquat. Sci. 2431:7-16.

LeBlanc, A. R., T. Landry \& G. Miron. 2003. Identification of fouling organisms covering mussel lines and impact of a common defouling method on the abundance of foulers in Tracadie Bay, Prince Edward Island. Can. Tech. Rep. Fish. Aquat. Sci. 2477: vii + 18 p.
Lee, R. J. \& A. D. Younger. 2002. Developing microbiological risk assessment for shellfish purification. Int. Biodeterior. Biodegrad. 50:177-183.

Lesser, M. P., S. E. Shumway, T. Cucci \& J. Smith. 1992. Impact of fouling organisms on mussel rope culture: interspecific competition for food among suspension-feeding invertebrates. J. Exp. Mar. Biol. Ecol. 165:91-102.

Levasseur, M., J.-Y. Couture, A. Weise, S. Michaud, M. Elbrächter, G. Sauvé \& E. Bonneau. 2003. Pelagic and epiphytic summer distributions of Prorocentrum lima and P. mexicanum at two mussel farms in the Gulf of St. Lawrence, Canada. Aquat. Microb. Ecol. 30:283-293.

Lilly, E. L., D. M. Kulis, P. Gentien \& D. M. Anderson. 2002. Paralytic shellfish poisoning toxins in France linked to a human-introduced strain of Alexandrium catenella from the western Pacific: evidence from DNA and toxin analysis. J. Plankton Res. 24:443-452.

Locke, A., M. Hanson, K. M. Ellis, J. Thompson \& R. Rochette. 2007. Invasion of the southern Gulf of St. Lawrence by the clubbed tunicate (Styela clava Herdman): potential mechanisms for invasions of Prince Edward Island estuaries. J. Exp. Mar. Biol. Ecol. 342:6977.

Lodge, D. M., R. A. Stein, K. M. Brown, A. P. Covich, C. Brönmark, J. E. Garvey \& S. P. Klosiewski. 1998. Predicting impact of freshwater exotic species on native biodiversity: Challenges in spatial scaling. Aust. J. Ecol. 23:53-67.

Luckenbach, M. W. 2001. Ecological interactions associated with cultured and restored bivalve populations in Chesapeake Bay. In. Puget Sound Research 2001.

MacDonald, J., G. MacCallum \& N. MacNair. 2005. Biofouling control in mussel farming on Prince Edward Island. In: Aquaculture Canada 2005. St. John's, NF.

Mack, R. N., D. Simberloff, W. M. Lonsdale, H. Evans, M. Clout \& F. A. Bazzaz. 2000. Biotic invasions: causes, epidemiology, global consequences, and control. Ecol. Appl. 10:689-710

Maggs, C. A. \& H. Stegenga. 1999. Red algal exotics on North Sea coasts. Helgol. Meeresunters. 52:243-258.

Malinowski, K. C. \& J. Ramus. 1973. Growth of the green alga Codium fragile in a Connecticut estuary. J. Phycol. 9:102-110.

Mann, R. 1983. The role of introduced bivalve mollusc species in mariculture. J. World Maricul. Soc. 14:546-559.

McCombie, H., S. Lapègue, F. Cornette, C. Ledu \& P. Boudry. 2005. Chromosome loss in bi-parental progenies of tetraploid Pacific oyster Crassostrea gigas. Aquaculture. 247:97-105.

McKindsey, C. W., M. R. Anderson, P. Barnes, S. Courtenay, T. Landry \& M. Skinner. 2006. Effects of shellfish aquaculture on fish habitat. DFO Can. Sci. Advis. Sec. Res. Doc. 2006/011: viii + $84 \mathrm{p}$.

McQuaid, C. D. \& T. E. Phillips. 2000. Limited wind-driven dispersal of intertidal mussel larvae: in situ evidence from the plankton and the spread of the invasive species Mytilus galloprovincialis in South Africa. Mar. Ecol. Prog. Ser. 201:211-220.

Meeuwig, J. J., J. B. Rasmussen \& R. H. Peters. 1998. Turbid waters and clarifying mussels: Their moderation of empirical chl:nutrient relations in estuaries in Prince Edward Island, Canada. Mar. Ecol. Prog. Ser. 171:139-150.

Messing, R. H. \& M. G. Wright. 2006. Biological control of invasive species: solution or pollution? Front. Ecol. Environ. 3:132-140.

Minchin, D. 1996. Management of the introduction and transfer of marine molluscs Aq. Cons. Mar. Freshw. Ecosys. 4:229-244.

Minchin, D., C. B. Duggan, J. M. C. Holmes \& S. Neiland. 1993. Introduction of exotic species associated with Pacific oyster transfers from France to Ireland. ICES CM 1993/F:27: 11 pp.

Minchin, D. \& H. Rosenthal. 2002. Exotics for stocking and aquaculture, making correct decisions. In: E. Leppäkoski, S. Gollasch $\&$ S. Olenin, editors. Invasive aquatic species of Europe: Distribution, impacts and management. Dordrecht: Kluwer Academic Publishers. pp. 206-215. 
Mineur, F., C. Maggs, M. P. Johnson, T. Belsher \& M. Verlaque. 2004. Vectors for introduction of alien macroalgae in Europe: oyster transfers. In: 13th International Conference on Aquatic Invasive Species. Ennis, Ireland. pp. 158.

National Research Council. 2004. Nonnative oysters in the Chesapeake Bay. Washington: National Academies Press. 344 pp.

Naylor, R.L., S.L. Williams \& D.R. Strong. 2001. Aquaculture-a gateway for exotic species. Science 294:1655-1656.

Nehls, G., S. Diederich, D. W. Thieltges \& M. Strasser. 2006. Wadden Sea mussel beds invaded by oysters and slipper limpets: competition or climate control? Helgol. Mar. Res. 60:135-143.

Nehring, S. 2006. Four arguments why so many alien species settle into estuaries, with special reference to the German river Elbe. Helgol. Mar. Res. 60:127-134.

Neushul, M., C. D. Amsler, D. C. Reed \& R. J. Lewis. 1992. Introduction of marine plants for aquaculture purposes. In: A. Rosenfield \& R. Mann, editors. Dispersal of living organisms into aquatic ecosystems. College Park: Maryland Sea Grant. pp. 103-135.

O’Beirn, F. X., M. W. Luckenbach, J. A. Nestlerode \& G. M. Coates. 2000. Oyster recruitment as a function of substrate type and tidal height. J. Shellfish Res. 19:387-395.

O’Beirn, F. X., P. G. Ross \& M. W. Luckenbach. 2004. Organisms associated with oysters cultured in floating systems in Virginia, USA. J. Shellfish Res. 23:825-829.

O'Mahony, J. H. T. 1993. Phytoplankton species associated with imports of the Pacific oyster Crassostrea gigas, from France to Ireland. ICES CM 1993/F:26: 8 pp.

Orensanz, J. M., E. Schwindt, G. Pastorino, A. Bortolus \& G. Casa. 2002. No longer the pristine confines of the world ocean: a survey of exotic marine species in the southwestern Atlantic. Biol. Invasions 4:115-143.

Orr, R. 2003. Generic nonindigenous aquatic organisms risk analysis review process. In: G. M. Ruiz \& J. T. Carlton, editors. Invasive species: vectors and management strategies. Washington: Island Press. pp. 415-431.

Osman, R. W. \& R. B. Whitlatch. 1995a. Ecological factors controlling the successful invasion of three species of ascidians into marine subtidal habitats of New England. In: N. C. Balcom, editor. Proceedings of the Northeast Conference on Non-Indigenous Aquatic Nuisance Species. Cromwell, Connecticut. pp. 49-60.

Osman, R. W. \& R. B. Whitlatch. 1995b. The influence of resident adults on recruitment: a comparison to settlement. J. Exp. Mar. Biol. Ecol. 190:169-198.

Osman, R. W. \& R. B. Whitlatch. 1995c. The influence of resident adults on larval settlement: experiments with four species of ascidians. J. Exp. Mar. Biol. Ecol. 190:199-220.

Osman, R. W. \& R. B. Whitlatch. 2004. The control of the development of a marine benthic community by predation on recruits. J. Exp. Mar. Biol. Ecol. 311:117-145.

Otwell, W. S., G. E. Rodrick \& R. E. Martin. 1991. Molluscan shellfish depuration. Boca Raton: CRC Press. 384 pp.

Penna, A., E. Garcés, M. Vila, M. G. Giacobbe, S. Fraga, A. Lugliè, I. Bravo, E. Bertozzini \& C. Vernesi. 2005. Alexandrium catenella (Dinophyceae), a toxic ribotype expanding in the NW Mediterranean Sea. Mar. Biol. 148:13-23.

Prins, T. C., A. C. Smaal \& R. F. Dame. 1998. A review of the feedbacks between bivalve grazing and ecosystem processes. Aquat. Ecol. 31:349-359.

Ramus, J. 1971. Codium, the invader. Discovery. 6:59-68.

Reise, K. 1998. Pacific oysters invade mussel beds in the European Wadden Sea. Senckenb. Marit. 28:167-175.

Reise, K., S. Olenin \& D. W. Thieltges. 2006. Are aliens threatening European aquatic coastal ecosystems? Helgol. Mar. Res. 60:7783.

Ribera Siguan, M. A. 2003. Pathways of biological invasions of marine plants. In: G. M. Ruiz \& J. T. Carlton, editors. Invasive species: vectors and management strategies. Washington: Island Press. pp. $183-226$.

Ricciardi, A. \& J. B. Rasmussen. 1998. Predicting the identity and impact of future biological invaders: a priority for aquatic resource management. Can. J. Fish. Aquat. Sci. 55:1759-1765.

Rodriguez, L. F. 2005. Novel habitats created by non-indigenous species: The role of oysters and ascidians as biological substrata for fouling communities. In: M. Carman, editor. International invasive sea squirt conference. Woods Hole Oceanographic Institution. pp. $17 / 59$.

Rosenfield, A. 1992. Risks associated with translocations of biological agents. In: A. Rosenfield \& R. Mann, editors. Dispersal of living organisms into aquatic ecosystems. College Park: Maryland Sea Grant. pp. 3-12.

Ross, K. A., J. P. Thorpe \& A. R. Brand. 2004. Biological control of fouling in suspended scallop cultivation. Aquaculture. 229:99116.

Rueness, J. 1989. Sargassum muticum and other introduced Japanese macroalgae: Biological pollution of European coasts. Mar. Pollut. Bull. 4:173-176.

Ruesink, J. L., H. S. Lenihan, A. C. Trimble, K. W. Heiman, F. Micheli, J. E. Byers \& M. C. Kay. 2005. Introduction of non-native oysters: ecosystem effects and restoration implications. Annual Review of Ecology, Evolution, and Systematics 36:643-689.

Ruiz, G. M. \& J. T. Carlton. 2003. Invasive species: vectors and management strategies. Washington: Island Press. 518 pp.

Ruiz, G. M., P. Fofonoff, A. H. Hines \& E. D. Grosholz. 1999. Nonindigenous species as stressors in estuarine and marine communities: Assessing invasion impacts and interactions. Limnol. Oceanogr. 44:950-972.

Ruiz, G. M., P. W. Fofonoff, J. T. Carlton \& A. H. Hines. 2000. Invasion of coastal marine communities in North America: apparent patterns, processes, and biases. Ann. Rev. Ecol. Syst. 31:481-531.

Scarratt, A. M., D. J. Scarratt \& M. G. Scarratt. 1993. Survival of live Alexandrium tamarense cells in mussel and scallop spat under simulated transfer conditions. J. Shellfish Res. 12:383-388.

Seaman, M. N. L. \& M. Ruth. 1997. The molluscan fisheries of Germany. In: C. L.. Mackenzie, Jr., V. G.. Burrell, Jr., A. Rosenfield \& W. L. Hobart, editors. The history, present condition, and future of the molluscan fisheries of North and Central America and Europe, Volume 3, Europe: NOAA Tech. Rep. 129. pp. 57-84.

Seed, R. 1996. Patterns of biodiversity in the macro-invertebrate fauna associated with mussel patches on rocky shores. J. Mar. Biol. Ass. UK. 76:203-210.

Seed, R. \& T. H. Suchanek. 1992. Population and community ecology of Mytilus. In: E. Gosling, editor. The mussel Mytilus: ecology, physiology, genetics and culture. Amsterdam: Elsevier. pp. 87-169.

Sekiguchi, K., S. Sato, T. Ogata, S. Kaga \& M. Kodama. 2001. Accumulation and depuration kinetics of paralytic shellfish toxins in the scallop Patinopecten yessoensis fed Alexandrium tamarense. Mar. Ecol. Prog. Ser. 220:213-218.

Shatkin, G., S. E. Shumway \& R. Hawes. 1997. Considerations regarding the possible introduction of the Pacific oyster (Crassostrea gigas) to the Gulf of Maine: a review of global experience. J. Shellfish Res. 16:463-477.

Shumway, S. E., C. Davis, R. Downey, R. Karney, J. Kraeuter, J. Parsons, R. Rheault \& G. Wikfors. 2003. Shellfish aquaculture - in praise of sustainable economies and environments. World Aquacult. 34:15-18.

Simard, N. \& M. Hardy. 2004. The Laurentian Channel as an alternative ballast water exchange zone: risks, analysis and recommendations. DFO Can. Sci. Advis. Sec. Res. Doc. 2004/120: iii + $74 \mathrm{p}$.

Smaal, A. C., M. Van Stralen \& J. Craeymeersch. 2005. Does the introduction of the pacific oyster Crassostrea gigaslead to species shifts in the Wadden Sea? In: R. Dame \& S. Olenin, editors. The comparative roles of suspension feeders in ecosystems. Volume 47 , 
NATO Science Series: IV-Earth and Environmental Sciences. Dordrecht: Kluwer. pp. 277-289.

Smayda, T. J. \& C. S. Reynolds. 2001. Community assembly in marine phytoplankton: application of recent models to harmful dinoflagellate blooms. J. Plankton Res. 23:447-461.

Springer, J., S. E. Shumway, J. M. Burkholder \& H. B. Glasgow. 2002. Interactions between the toxic estuarine dinoflagellate, Pfiesteria piscicida, and two species of bivalve molluscs. Mar. Ecol. Prog. Ser. 245:1-10.

Stachowicz, J. J., H. Fried, R. W. Osman \& R. B. Whitlach. 2002. Biodiversity, invasion resistance, and marine ecosystem function: reconciling pattern and process. Ecology. 83:2575-2590.

Stachowicz, J. J., R. B. Whitlach \& R. W. Osman. 1999. Species diversity and invasion resistance in a marine ecosystem. Science 286:1577-1579.

Streftaris, N., A. Zenetos \& E. Papathanassiou. 2005. Globalisation in marine ecosystems: The story of non-indigenous marine species across European seas. Oceanogr. Mar. Biol. Ann. Rev. 43:419453.

Suchanek, T. H. 1979. The Mytilus californianus community: studies on the composition, structure, organization, and dynamics of a mussel bed. Ph.D. thesis, University of Washington, Seattle. pp. 286.

Suchanek, T. H. 1981. The role of disturbance in the evolution of life history strategies of the intertidal mussels Mytilus edulis and Mytilus californianus. Oecologia. 50:143-152.

Suchanek, T. H. 1985. Mussels and their rôle in structuring rocky shore communities. In: P. G. Moore \& R. Seed, editors. The ecology of rocky coasts. London: Hodder and Stroughton. pp. 70-96.

Swan, K., J. Davidson \& T. Landry. 2005. The effect of treatment regimes on the physiological fitness of the Prince Edward Island cultured blue mussel Mytilus edulis population. In: AquaNet V. Victoria, BC. pp. E41.

Tenore, K. R. \& N. González. 1976. Food chain patterns in the Ria de Arosa, Spain: an area of intense mussel aquaculture. In: G. Persoone \& E. Jaspers, editors. Proceedings of the 10th European Symposium on Marine Biology, Ostend, Belgium, September 17-23, 1975. Vol 2: Population dynamics of marine organisms in relation with nutrient cycling in shallow waters. Wetteren: Universa Press. pp. 601-619.

Thompson, R. \& N. MacNair. 2004. An overview of the clubbed tunicate (Styela clava) in Prince Edward Island. Prince Edward Island Agriculture, Fisheries and Aquaculture Technical Report 234: viii +29 pp.
Trowbridge, C. D. 1998. Ecology of the green macroalga Codium fragile (Suringar) Hariot 1889: invasive and non-invasive subspecies. Oceanogr. Mar. Biol. Ann. Rev. 36:1-64.

Tsujino, M., T. Kamiyama, T. Uchida, M. Yamaguchi \& S. Itakura. 2002. Abundance and germination capability of resting cysts of Alexandrium spp. (Dinophyceae) from faecal pellets of macrobenthic organisms. J. Exp. Mar. Biol. Ecol. 271:1-7.

Vercaemer, B., K. Spence, E. Kenchington, A. Mallet \& J. Harding. 2003. Assessment of genetic diversity of the European oyster (Ostrea edulis) in Nova Scotia using microsatellite markers. Can. Tech. Rep. Fish. Aquat. Sci. 2453: v +30 pp.

Verlaque, M. 2001. Checklist of the macroalgae of Thau Lagoon (Herault, France), a hot spot of marine species introduction in Europe. Oceanol. Acta. 24:29-49.

Wallentinus, I. 2002. Introduced marine algae and vascular plants in European aquatic environments. In: E. Leppäkoski, S. Gollasch \& S. Olenin, editors. Invasive aquatic species of Europe: Distribution, impacts and management. Dordrecht: Kluwer Academic Publishers. pp. 27-52.

Wasson, K., C. J. Zabin, L. Bedinger, M. C. Diaz \& J. S. Pearse. 2001. Biological invasions of estuaries without international shipping: the importance of intraregional transport. Biol. Conserv. 102: 143-153.

Whitlatch, R. B., R. W. Osman, A. Frese, R. Malatesta, P. Mitchell \& L. Sedgwick. 1995. The ecology of two introduced marine ascidians and their effects on epifaunal organisms in Long Island Sound. In: N. C. Balcom, editor. Proceedings of the Northeast Conference on Non-Indigenous Aquatic Nuisance Species. Cromwell, Connecticut. pp. 29-48.

Wijsman, J. W. M. \& A. C. Smaal. 2006. Risk analysis of mussel transfer. Wageningen IMARES (Institute for Marine Resources \& Ecosystem Studies). 103 pp.

Wikström, S. A. \& L. Kautsky. 2004. Invasion of habitatforming seaweed: effects on associated biota. Biol. Invasions 6:141-150.

Wolff, W. J. \& K. Reise. 2002. Oyster imports as a vector for the introduction of alien species into Northern and Western European coastal waters. In: E. Leppäkoski, S. Gollasch \& S. Olenin, editors. Invasive aquatic species of Europe: distribution, impacts and management. Dordrecht: Kluwer Academic Publishers. pp. 193-205.

Wonham, M. J. \& J. T. Carlton. 2005. Trends in marine biological invasions at local and regional scales: the Northeast Pacific Ocean as a model system. Biol. Invasions 7:369-392. 